\title{
THE IDEOLOGICAL BACKGROUND OF JAPANESE EXPANSIONISM, C. 1900
}

\begin{abstract}
This paper examines the ideologies informing the expansion of Japanese rule at c. 1900. The core feature discussed is the idea of tenka (天下; literally translated: all under heaven), constituting the group of ruled in terms of a universalist indigenat (kokumin 国民), which allowed its expansion beyond the Japanese archipelago at government discretion. The concept of the universalist indigenat, having been tied to the Confucian perception of the world as a well-ordered and change-absorbing entity, conflicted with the European concept of the nation as a particularistically conceived type of group, tied to the perception of the world as a dynamic and largely unruly entity. During the latter third of the nineteenth and the early years of the twentieth century, some Japanese intellectuals came to appreciate the dynamism enshrined in the European perception of the world and worked it into established universalism. The fusion produced a powerful ideology of colonial expansion targeted primarily at East and Southeast Asia as well as the South Pacific. By contrast, European military strategists and political theorists, unaware of the Japanese strategic conceptions, expected that solely Russia formed the target of Japanese military expansion.
\end{abstract}

Keywords: colonialism; Pan-Asianism; universalism

doi: 10.2478/sho-2021-0002

INTRODUCTION:

THE EMERGENT CLASH OF CONCEPTS OF RULE: UNIVERSALISM VERSUS TERRITORIALISM

How can the unprecedented expansion of Japanese rule over parts of East Asia and the South Pacific between 1872 and 1914 be explained? On the one hand, Seaton [2017] has constructed a metaphysical, apparently long- 
term process of expansion from a nucleus in the centre of the archipelago during the Nara Period (710-784) to the collapse of overseas colonial rule in 1945. On the other hand, Beasley and Kublin [Beasley W.G. 1987: 251, 254, 258; Kublin H. 1959; Peattie M.R. 1984] $]^{1}$ have argued that the Meiji (1868-1912) and the Taishō (1912-1926) government ${ }^{2}$ pursued, from the 1890s, a long-term strategy of expansion focused upon economic gains by way of incrementally securing control over territorities in ever more remote areas, and based their argument on contemporary assessments mainly by British strategists [United Kingdom of Great... 1912: 210]. ${ }^{3}$ Both explanations rest on the hypothesis that there was some grand strategy of expansion. But what is the evidence supporting this hypothesis? The first and foremost difficulty is that the hypothesis includes the systemic expectation that, on principle, relations among states take place in a quasi-Hobbesian "state of nature" without abidance by overarching norms. Against this expectation, however, up until the early nineteenth century, the intercourse between states in East Asia as well as relations between East Asia and Europe reveal fundamental law-based patterns that were taken to exist as such, without having to be legislated in one form or another. These patterns included the understanding that, in each state, rulers were granted the power to regulate admission to territories under their control, specifically for traders; the wide-spread universalism as the underlying concept of rule rendered spatial boundaries temporary and, in many cases, zonal. The ruled formed indigenats overarching hybridity and legal pluralism. Thus, the sovereignty of Japan and her subjectivity under the unset law among states were taken as a matter of fact in East Asian as well as European perspective. In Japan, in line with the Chinese model, ${ }^{4}$ the well-researched universalist principle was valid according to which the territory of a ruler extended as far as the manifest control of that ruler reached from the centre to the periphery. In European perspective, China and Japan ranked as "empires" under a ruler, to whom, as the believed

${ }^{1}$ Peattie M.R. [1984] at 91-2 agrees with Kublin on principle but does not admit purely economic interests related to material gains, dominating all other motives.

2 I use the word "government" as an institutional collective singular for the several incumbent governments of the period to denote long-term continuities in polocy-making.

3 The economics-based interpretation of Japanese colonial rule goes back to work by Nitobe I. [1920].

${ }^{4}$ For studies on the centre-periphery relations in East Asia on the Ch'ing Tributary System see Fairbank J. K., Teng S.Y. [1941]; Mancall M. [1970]; Gipouloux F. [2011]; Hamashita T. [1997]; Hevia J.L. [2009]; Perdue P.C. [2015]; Suzuki S. [2009: 34-55]; Tashiro K. [1982]; Wang G.-W. [2013: 131-152]. Zhāng Y., Buzan B.G. [2012]; Zhào T.Y. [2020: 50-121]. 
overlord over several "kings", European observers awarded the title "emperor" (imperator) suggesting the supremacy of this ruler and legal equality with rulers of the same rank in Europe. Norms of the unset law among states, derived from the perceived naturally given order of the world, were fairly strictly observed in relations between Europe and Japan. ${ }^{5}$ This came on record already early in the seventeenth century. In 1627, Pieter Nuyts, who had just been appointed Governor of the Dutch East India Company (VOC) settlement in Taiwan, went on a mission to the Shōgun 将軍 but was eventually turned back. The Shogunal government carefully checked the letter of credence that Nuyts had received from company headquarters at Batavia, concluded that Nuyts had not been dispatched by a sovereign, neither in Java nor in the Netherlands, and refused to admit him citing that the Shoggun would only receive emissaries dispatched by a ruler of equal rank. Nuyts accepted the argument and withdrew. ${ }^{6}$ Both sides underwrote the principle of managed trade and the VOC implemented the government's order to establish its trading sport on the artificial island of Dejima in Nagasaki port [Dutch East India Company...: CLIX; Speelman C. 1685: 189].

Completely in line with the natural-law tradition behind the universalist concept of rule, the coastlines of the Japanese archipelago remained undefended well into the early nineteenth century, except for a few fortified spots spotted on the coast and despite early warnings against the possibility of invasions. Hence, to 1825 , Japan was not a "closed country". ${ }^{7}$ In that year, the Shogunal government responded to the increasing number of European and US-American ships cruising in the North Pacific, with some

${ }^{5}$ On the recognition of unset natural law in East and Southeast Asian perspective in, among others, the theoretical text Taj us-Salatin (The Crown of All Kings, 1603) by Malayan author Bukhari al-Jauhari from Johor [Bukhari al-Jauhari 1603] see Weststeijn A. [2017: 2336]; Zachmann U.M. [2016: 167]. On the ranking of Japan as empire positioned above kingdoms (regna) see, among others, Brixianus Organtinus [1605: 206, 212]; Varenius B. [1673: chap. 4, 7; pp. 11-4, 21-3]. On the parallelism between East Asian and European natural law traditions see Maruyama M. [1952: 185, 204; 1974: 179-80, 196, 198, 200].

${ }^{6}$ On the mission of Pieter Nuyts see Clulow A. [2013: 95-134]; Matsukata F. [2018: 83-5].

7 The possibility of access to the archipelago was argued by Hayashi S. [1738-1793 1785/1916], who portrayed the ocean as open to everyone. On this text see Amino Y. [1995; 2003]. The phrase "closed country" was created by Engelbert Kaempfer [2001: 255]. Kaempfer described Japan, as he perceived it, as a territory to which non-Japanese persons had only strictly regulated access under close government surveillance. Kaempfer's phrase appeared in a Japanese rendering as sakoku 鎖国 first in 1801, in: Shizuki T. [1801/1914]. For studies see Ōshima A. [2005; 2006; 2009: 137-204]; Zöllner R. [2003]. 
Russian vessels landing on the coast of Hokkaidō as well as in Nagasaki port, and came to the conclusion that some general rule had to be enacted regulating access to the entire archipelago. It released the edict on the repulsion of foreign ships (Ikokusen uchiharai-rei 異国船内原玲令), which was to be used against all vessels arriving in Japan under American and European flags other than the Dutch and remained in force until 1842. ${ }^{8}$

In the same year 1825, scholar Aizawa Seishisai (会沢正志斉, 17821863), in a short text on the Japanese state, took an explicit stance against European penetration into the North Pacific, denouncing the crews of European ships as uncivilised barbarians from the far Western fringes of the permeable ecumene, in accordance with the conventional Chinese world picture [Gotenjiku-zu 五天筑図 (map of the world)...]. ${ }^{9}$ The barbarians, he expected, wanted to establish trade relations for the sole purpose of spying in Japan and ruining the economy [Aizawa S. 1973: 94-5; Wakabayashi B.T. 1986: 200]. Aizawa's comment put on record the emergent clash of concepts of rule. The clash was one between the Japanese universalist as well as inclusionist concept of rule, leaving the boundaries of the state unmarked, and a particularist as well as exclusionist concept, demanding the unequivocal demarcation of state territory and informing the strategies and policies pursued by European and North American governments engaged in activities in the North Pacific. Whereas East Asian universalism rooted in the naturally ordained legal order of the world, European and North American particularism rested on the postulated need for the demarcation of state territory and the positive recognition of these demarcations in written agreements established under the European international law of treaties among states. By consequence, areas, including groups of islands, not being recognised in European and North American perspective as parts of state territory, could rank as lordless areas, ready for future European and North American occupation. The lack of compatibility of both conceptions of rule formed the background, against which governments in Europe and North America pursued strategies of expansion in the North Pacific from the 1820s. From 1853, European and North American governments articulated these strategies with displays of military potential and amplified them into the demand that Japan as a state should be "opened" for trade.

\footnotetext{
${ }^{8}$ For a study of the edict of 1825 see Toby R.P. [1984: 168-230]; Tsuzuki C. [2000].

9 This type of world map remained productive to the end of the eighteenth century: original of 1749 in the Kobe City Museum.
} 


\section{TRANSFORMING THE STATE STRUCTURE AND DESIGNING THE LOGIC OF THE EXPANSION OF GOVERNMENT CONTROL IN JAPAN}

These strategies paved the way for the forced transformations of the state structure jointly with the adoption and modifications of European norms and values. As the pragmatics of these transformation processes have often been described ${ }^{10}$ I shall not refer to them here. Instead, I shall focus on the response pursued by the Meiji and the Taishō government towards the external pressures under which they undertook to enforce the transformation. The most straightforward record of the intricacies involved in the transformation processes is a monograph, which Katō Hiroyuki (加藤弘之， 1836-1916), influential government advisor and rector of the Academy of Sciences, published in German in 1894 and in which he explicated his own program of expansion in terms of the establishment of Japan as a colonial power. ${ }^{11}$ The text breathed the spirit of evolutionionist social Darwinist theories informing European ideologies of colonial rule, drew on borrowings from nationalist and biologist European theories of state and society, urged the government to launch a civilisation mission for the alleged perfection of humankind at large and gave expression to a dynamic, progressist perspective on the future. Katō deemed colonial rule "natural". In Katō's view, unlike in the previous natural-law tradition, nature was not a stabilising force of the world but a paradigm for justifying dynamic human action of various kinds, appearing to demand recognition as the force dominating law and morality. In his progressist perspective, Katō envisaged the coming of a future world state, which he framed as a confederation under international, not municipal law. His future world state appeared to him to be hierarchically ordered: "strong" states as holders of colonial rule and as manifestations of "civilisation" and "virility" were to dominate "weak", "feminine" and "uncivilised" states. According to Katō, colonial rule was unlawful and immoral but justified by "nature" as long as it served the ultimate purpose of bringing to perfection humankind through the expansion of "strong" states. As Katō included Japan into the club of the "strong" states, she was, in his view, entitled to be in

${ }^{10}$ For a recent overview of the transformation see Takii K. [2007].

11 Katō H. [1893: 177-86]. Similarly Tokutomi S. [1894: 1-2], who, in the course of the Sino-Japanese War, argued in favour of the expansion of Japanese rule through migration to China; also Kaneko K. 1904a: 28. 
control of colonies. Katō thus used the European ideology of colonial rule in order to justify colonial expansion in Japan.

Katō's program of colonial policy made explicit two fundamental features of the foreign policy of the 1890s: first the accomplishment of legal and political equality with the European governments as apparent great powers and, second, the fusion of great-power status with colonial rule. The revision of the non-reciprocal treaties which the Japanese government had been forced to conclude with European and North American governments between 1854 and 1869, was the first and foremost requirement for the accomplishment of legal and political equality with the European great powers.

This goal had been declared already in 1868 [Japan, Gaimushō... 1938]. ${ }^{12}$ Katō did not even have to refer to it, even though, at the time of writing, all of the non-reciprocal treaties were still in force. But his arguments added to the pressure on the Meiji government to finally accomplish the revision. In 1893, the second feature of Katō's program awaited implementation. But he was setting the cornerstones for the Japanese strategy ready for use in the upcoming Sino-Japanese War of 1894/95, resulting in the subjection of Taiwan to Japanese colonial rule. The plan for the expansion of Japanese control beyond the archipelago did not only not contradict its collective victimisation in consequence of European and North American penetration into East Asia and the North Pacific, but the initial victimisation was the condition for the subsequent emergence of the strategy of colonial expansion. ${ }^{13}$ Moreover, the expansion was consistent with the adjustment of the traditional universalistic state structure to the positive legal regimes and progressist conceptions enshrined in the normative framework of the globalised European international system. In this system, the expansion of rule counted as a privilege of great powers and appeared to be implementable through the establishment of colonial rule. Katō placed Japan as a hoard of stability and, at the same time, a catalyser of systemic change in this world of states.

However, the Meiji government did not take over Katō's program of colonial expansion as a whole, but deviated from it with regard to two major

12 Higashikuze M. [1992: 521 [entry on 12 February 1868 = 19th day of the first month of year Keio 4]. The US envoy reported the communication on 16 February 1868; see Treat P.J. [1932: 344]. On treaty revision see Araki T.J. [1959]; Auslin M.R. [2004: 146-75]; Hora T. [1977]; Ishii K., Sekiguchi H. [1982]; Mitani H. [2006: 271-86]; Siebold A. [1900: 1-5, 40-8].

13 Thus explicitly Katō H. [1870: 90]; Kaneko K. [1904b]; Peace treaty of Shimonoseki... [1981]. 
points. The first point concerned terminology. Whereas Katō did not shy away from using words characteristic of European imperialist great-power ideology, the Meiji government carefully avoided the use of imperialist-colonialist diction in its official statements and the denomination of its institutions. The second point referred to the concretisation of colonial administration, as it became implemented after the conclusion of the Sino-Japanese War in 1895. While Katō was ready to write off the states he ranked as "weak" and "uncivilised", the Meiji government raised the advancement of "civilisation" to the main goal of its own program for the implementation of colonial rule with specific concern for Taiwan. That the Meiji government took these steps against Katō's theoretical advice, was the result of the reception into government policy of thought patterns of Pan-Asianism [[Takayama] 1930: 313; similarly Nitobe 1920: note 4, 120-1]. ${ }^{14}$

\section{BETWEEN ANTI-COLONIAL RESISTANCE AND THE IMPOSITION OF COLONIAL RULE}

Initially an ideology of anti-colonial resistance, Pan-Asianism stood against strategies towards the expansion of rule beyond Japan. This was so because the declared Pan-Asianist goal was the uniting of Asia, specifically East, Southeast and South Asia through the lifting of European colonial control. According to the demands of early Pan-Asianists, Japan as a state, after its self-liberation from European-imposed political inequality vis-à-vis the great powers, was given the obligation to liberate Asia through some "civilising" process (bunmeika 文明化). ${ }^{15}$ Pan-Asianism, however, soon came to serve as an ideological catalyser to the end of passing Japanese political influence in China as well as the intensification of Japanese rule in Taiwan and Korea off as acts of the removal of European, specifically Russian, pressure and, further, of imposing Japanese "progress" upon East and Southeast Asia. Pan-Asianism thus was designed to kick off transformations following the Japanese model, thereby in turn advancing

14 For the context of Panasianism see Aydin C. [2007: 54-9, 161-89]; Hiraishi N. [1998]; Hotta E. [2007: 75-106]; Miwa K. [2007]; Nakano R. [2013]; Saaler Sven [2011]; Takeuchi Y. [1963].

15 Thus Okakura T. [1903: 1, 5-8; 1943: 223]; Kaneko K. [1904b: 197-8]. Already in 1875 Fukuzawa Yukichi subsumed into this concept the increase of the internal strength of the Japanese state and the establishment of Japanese colonial rule over parts of Asia [Fukuzawa Y. 1875]. 
the influence of the Japanese government [Sakuma S. 1916: 4-5]. But this line of argument had its flaws from the very beginning. Domestic rightwing critics of the government's anti-Russian strategy argued that the war against Russia, apparently fought to remove alien control from East Asia, had jeopardised the security both of Japan and of East Asia. For, even if Russia had withdrawn from Chinese territory, other European governments were still there and would now threaten even Japan's increased military strength while the Japanese armed forces were not ready to stand up against this threat. In Socialist perspective, the Meiji government appeared not just to imitate practices of European colonial rule but also to take over all the evils to which Japan had been exposed before. ${ }^{16}$ The Meiji and, subsequently, the Taishō government, however, remained unimpressed by these brands of criticism. Instead, they felt encouraged to join their expansionist strategy with an ideology of liberation and did so on the basis of the alliance with the United Kingdom. As late as in 1914, PanAsianism provided the argumentative background for the formulation of Japan's official war aims [Japanese declaration of war... 1914; on the alliance see Nish I.H. 1966].

Already during World War I, the Taishō government responded defensively to critical junctures elsewhere in the world, which they took to be advantageous for themselves. Following the beginning of hostilities in the European war theatre, Japan issued to Germany an ultimatum on 17 August 1914 demanding the withdrawal of German warships from East Asia, the dismantlement of ships that could not be withdrawn, and the surrender of the Shandong territory to Japanese control to the end of later returning Shandong to the Chinese government [Beer M. 1915: 369-70].

Yet neither the naval command and the government took any steps aimed at exploiting the newly occupied island worlds nor were they concerned about issues relating to trade. A report on the administration of the islands that the Ministry of Education (Monbushō 文部省) released in 1916, neither featured statements concerning natural resources nor did it portray the islands as target areas for future emigration. ${ }^{17}$ It was only in 1921 that the government disptached a fact-finding mission, which produced

16 Thus, for one, Ōkawa S. [1922: 13-18; 1926: 85-92]. For studies see Hashikawa B. [1964: 358]; Irie A. [1966: 4-8]; Ömori M. [1999]; Szpilman C.W. [2015: 53-75]. For criticism from a Socialist perspecive see, first and foremost, Kōtoku S. [1901: 19].

17 Japan, Monbushō [1916], only then taking up earlier proposals for settlement colonialism, among others by Ukita K. [1901, 1902, 1909: 2]. 
several research reports between 1925 and $1927 .{ }^{18}$ Hence, the argument is not tenable that, from the 1890s, there should have been a long-term government strategy of expansion focused exclusively on obtaining economic gains, and consistenly striving to expand the territory under their control by grabbing ever more remote outposts.

Under the revised Anglo-Japanese alliance agreement of 1911, the government, in 1917, granted support to the British fleet operating in the Mediterranean Sea against German submarines. In return, it obtained British recognition for its rule over the former German colonial dependencies in the South Pacific north of the Equator. The agreement of 1917 was classified, whence the British government informed only the then belligerents among its allies, not the USA [Pauwels P.C. 1936: 28-30]. ${ }^{19}$ The full contents of the agreement came to light only in the course of the Paris peace negotiations, when the Japanese delegation, backed by British support, requested confirmation for its control of the former German colonies in the South Pacific in the form of a League of Nations mandate. ${ }^{20}$ The conference agreed, and the League of Nations issued a Class C Mandate including the transfer of full sovereignty rights over the mandatory territories, thereby categorising the South Pacific islands as territories not ready for self-government in the long term [Maanen-Helmer E. 1929; Pauwels P.C. [1936: 30-73]. The US government recognised the mandate in the course of the Washington Conference. ${ }^{21}$

\section{INSTITUTIONALISING COLONIAL RULE}

Meanwhile, the Taishō government established the authorities required for the administration of the mandatory territories and waved the caution with which the Meiji government had employed European colonial terminology [League of Nations, Mandate... 1920]. Initially, there had neither been specialised administrative agencies, as the various ministries in charge did

18 Summarised in Japan, Monbushō [1927]. On the mandate administration see Clyde P.H. [1935]; Peattie M.R. [1988a: 186-90; 1988b: 243-67]; Purcell Jr. D.C. [1967: 146-246]; Yanaihara T. [1935].

${ }^{19}$ For a study see Burkman T.W. [2008: 1-28]; Saxon T.D. [2000].

${ }^{20}$ On the Japanese demands see Ninagawa A. [1919: 6-11]; Rōyama M. [1941: 28]; Shimada S. [1919: 19-24].

${ }^{21}$ In the colonial powers, former colonial officials and other commentators reinforced fears of Japan as an aggrandising colonial power; see, among others, Schnee H. [1922; 1941]; Seibold L. [1921]. 
not pool their specific competences regarding colonial affairs, but maintained them regardless of whether domestic or colonial matters were concerned [Yanaihara T. 1939: 23-8; 263-6, 268-71]. Nor had there been any specialised training for colonial administrators [Pauwels P.C. 1936: 80-1], even though Tokyo Imperial University and Waseda University had established one teaching and research institute each for colonial studies in 1908 and 1909 respectively and Hokkaidō University had operated a program of colonial studies. The imperial edict of 30 March 1922 finally created the South Sea Bureau (Nan'yō Chō 南洋庁) under the Prime Minister's office. The Bureau was advised by the new interministerial Colonial Office (Takumu Kyoku 拓夢省), and, in 1929, a fully-fledged Colonial Ministry came into existence (Takumu Shō 拓夢局). The official terms used for the office as well as the ministry, which was also in charge of the "development" (kaihatsu 開発) of Hokkaidō, ${ }^{22}$ reflected a developmentalist approach, through which the "civilisation" mission in the South Pacific island worlds was implemented in terms of practical administration [Pauwels P.C. 1936: 75, 79-80; Yanaihara T. 1939: 253, note 31; Peattie M.R. 1988b: 244, note 25; Duus P. 1992/1996]. ${ }^{23}$ The Imperial Navy remained present in the territories while leaving the administration to civilians, and refrained from the building of major defence works in adherence to the League of Nations Covenant. ${ }^{24}$ Population groups having come under Japanese sway were to become adapted to Japanese cultural habits (kōminka 公民化), the adoption was to lead to some rather nebulous progress of "civilisation" eventually resulting in the removal of European colonial rule. League of Nations rules for the administration of mandatory territores stood against the inclusion of the populations in the depending territories into an overarching Japanese collective identity. While applying the rhetoric of colonialism, the the Taishō government like its predecessor, treated imperialism (teikokushugi 帝国主義) as a purely Western ideology. ${ }^{25}$

22 Already at the turn of the nineteenth century, Honda Toshiaki 本多利明 (1743-1820) had proposed that the government should colonise not just Hokkaidō but even Kamchatka and should, after its complete refurbishing, establish its headquarters there: Honda T. [1970: 160].

${ }^{23}$ For evidence on the developmentalism practised by the Japanese colonial administration see Hirano Y., Kiyono K. [1942: 234]. For a study see Kibata Y. [2002].

${ }^{24}$ Edict by the South Sea Bureau, dated 11 October 1922, in: Japan, Nan'yō chō... [1927: Annex (s.p.)]. On the edict see Pauwels P.C. [1936: 78]. For the "industries" see Japan, Nan'yō chō....[1930: 19]. For a study see Peattie M.R. [1988a: 126-32].

${ }^{25}$ On the notion of imperialism (teikokushugi 帝国主義) as a matter of the West see Wallentowitz A. [2011: 261]. 
The conceptualisation and implementation of Japanese government colonial policy and administration stood in stark contrast against European practices. Whereas European governments opted either for the segregation of their nationals from populations in the colonial dependencies, most radically the German government to 1918, or, as the French government, demanded the assimilation of select people who had been isolated from their cultural backgrounds, the Taishō government, after initial hesitation to adopt the European colonialist terminology, integrated into its administration some aspects of colonial and domestic affairs on the one side, while, on the other side, it made efforts to separate the collective identities of the archipelago from those of populations in the dependencies and never imposed a single overarching legal framework over them [Japan, Takumushō...1937-1938; Japan, Takumushō... 1938]. ${ }^{26}$

In brief, the often recorded matter-of-factness turns consistent, with which, around 1900, contemporarary theorists were ready to fuse the territorial boundedness of the Japanese state (as "Empire") with expansionist ideologies, promoted Pan-Asianism as an ideology of anti-colonial liberation and ascribed to the government titles to rule over territories and populations beyond the archipelago, spotted mainly in Southeast Asia and the South Pacific (nanshin 南進) [Shiga S. 1889]. ${ }^{27}$ This fusion was by no means expression of the lack of intellectual penetration into purportedly stern principles of state reason and their rejection in favour of plain emotions; instead, the fusion was the result of the fitting of the tradition of the universalist concept of rule into the structures and procedures of the European international system.

\section{EUROPEAN RESPONSES TO JAPANESE EXPANSIONISM}

During the period leading up to World War I, Japanese expansionist ideologies appeared to boost policies that peaked in the Russo-Japanese War. The war eventually emerged as the turning-point in the European assessment of the fighting power of the Japanese armed forces compared to their Russian adversary. Whereas the anti-colonialist push of Pan-Asianism had been noticed in Europe already in the aftermath of the Sino-Japanese

${ }^{26}$ For studies see Gotō K. [1992]; Hatano S. [1986]; Lynn H.-G. [1998: 91].

${ }^{27}$ For studies see Gavin M. [2004a; 2004b: 65-98, 163-4]. Maeda A. [1973]; Miwa K. [1967: 140-89; 1970]; Peattie M.R. [1996: 198]; Shimizu H. [1991]. 
War of 1894/95, ${ }^{28}$ Russian defeat in 1905 appeared to suggest, specifically to German [Lauenstein O. 1905; Deutsches Reich... 1908: 126-7] military analysts, that on the one side, the likelihood of a Russian attack on a state in Central Europe was declining due to apparently wavering "moral determination" of the Russian fighting force, while, on the other, the threat of a Japanese attack on Russian territory in continental Northeast Asia was growing [Marmande R. 1904: 322-3; Stead A. 1904]. In turn, this prospect had implications for war planning mainly in the German Empire, as the declining probability of a Russian attack on Central Europe appeared to suggest that, under the constraints of the presumed secret military alliance between France and Russia, German armed forces might be in a position of attacking France on their western front without having to fear a simultaneous threatening Russian relief attack on their eastern front [Seligmann M.S. 2007: 116-22].

By 1905, the General Staff came to expect that the German armed forces would suffice to stand against a combined invasion by Russian and French forces, that the diminished Russian fighting force could be defeated with the German peacetime contingents deployed on the Eastern front and that, by consequence, the main fighting force could be shifted to the Western front against France. The General Staff even arrived at the conclusion that, Russia's military strength failing due to its defeat in 1905, a French preventive attack on Germany was unlikely, because, so the General Staff believed, Russia as France's alliance partner was not ready for an offensive move against the German Empire. Consequently, the German side expected that the French army, although prepared for war, would remain in defensive positions, most likely behind its line of fortifications on the French eastern front, would await a German attack and retaliate massively. The German side also assumed that the French military command had intelligence concerning German plans for offensive action and expected that the German armed forces would not directly attack the French line of fortifications but would lead their right wing through Belgium to circumvent the French fortifications in the north and attack from the rear [Schlieffen A. 1905; Greiner H. no date: fol. 95].

${ }^{28}$ Falkenegg Ledersteger A.P. 1905: 26, 46, 52]. Telegraphic Message by Sir C. Scott, British representative at St Petersburg, to the Marquess of Lansdowne [Scott C. 1901]. For comments see Seligmann M.S. [2007]. 


\section{CONCLUSION: COLONIAL IDEOLOGY AS A RESPONSE TO EUROPEAN PENETRATION INTO EAST AND SOUTHEAST ASIA AS WELL AS THE SOUTH PACIFIC}

In conclusion, the Meiji government, in its bid for recognition as a great power, based its adoption of European ideologies of colonial rule not only upon careful analysis but also upon ruthless assessment of its own interests, which it sought to pursue when circumstances appeared to be favourable. By contrast, the European response to the Japanese modification of European colonial ideologies boosted misperceptions which, in turn, supported the formation of illusionary war plans. Contrary to the recognisable Japanese policy of grabbing opportunities as they were coming along, European military planning postulated the pursuit of some grand strategy as the platform for the Japanese policy of colonial expansion at Russian expense. However, the perception of Japanese colonial rule as the outflow of some strategic design was the product of European imagination that had little in common with Japanese government intentions. European strategists assessed Japanese war-making capability solely according to its impact on Russian war-making capability while overlooking the upcoming Japanese military threat on European positions in continental East as well as Southeast Asia and the South Pacific. Consequently, European military planning was based on miscalculations serious enough to induce German ambassador in Japan Graf von Rex to telegraph to Qingdăo as late as on 9 August 1914 the message that Japan would not move against the place [Reported in: Vollerthun W. 1920: 32; Ostwald P. 1922: 162].

During the first decade of the twentieth century, an information gap arose between Europe and Japan and favoured Japanese diplomats, politicians and military strategists, all of whom, at high cost and with great intellectual effort, acquired knowledge about Europe, as if by way of enemy research. By contrast, European "world politicians" - no less nationalist than their Japanese rivals - had no means to close the information gap in the short term. They did not take notice of the early expansionist proposals for "Southward Advance" (nanshin 南進) but, relying on dubious material issued by militant secret societies [Jacob F. 2014; Joos J. 2011; Norman E.H. 1944], persuaded themselves that Japanese expansion was targeted solely at Northeast Asia, and believed that only Russia was the 
target. "World politics", ${ }^{29}$ in its then technical meaning, rested on the postulate of the reciprocal global interdependence of all military and political decisions of the self-appointed great powers potentially relating to every spot on the surface of the planet, and demanded the making of complex abstract scenarios of possible responses to decisions that had been taken, were in the making or to be expected, often to be worked out under acknowledged conditions of poor information. On its own side, since the end of the Russo-Japanese War, the Meiji and the Taishō government took several steps to demand connectivity in terms of seeking recognition as politically equal great power and pursued an offensive policy of world market penetration and cultural internationalism [Irie A. 1997: passim, esp. 37, 44-7]. However, it met, to put it mildly, with reluctance on the side of members of the club of self-appointed great powers. When, during the Paris Peace Conference, the Japanese delegation advanced its proposal to supplement the Wilsonian demand for the recognition of the freedom of religious practice, suggesting the insertion into the League of Nations Covenant the obligation to acknowlegde the "equal and just treatment in every respect making no distinctions, either in law or in fact, on account of their race or nationality", thereby again acting in conformity both with established universalism and Pan-Asianist ideology, US President Woodrow Wilson suppressed the debate arguing that it was mandatory "to quiet discussion that raises national differences and racial prejudices" [Shimazu N. 1998: 127; 2006: 149-70]. Australian Prime Minister William Morris ("Billy") Hughes (in office 1915-1923) concluded more bluntly: "The proposition is this: either the Japanese proposal means something or it means nothing. If the former, out with it; if the latter, why have it." [partly printed in: Macmillan M. 2001:328]. The proposal led nowhere but, in retrospect, provoked diplomat Shidehara Kijūrō 幣原喜重郎 (1872-1951) to identify the problems arising from the use of English as lingua franca at the international level. Shidehara, who was well versed in English, complained about Japanese delegates at the conference having repeatedly fallen victim to racist prejudice, mainly due to lack of command of a foreign language. He noted that the inappropriate use of a foreign language had exposed Japanese delegates to ridicule and sarkasm. Even more serious was, in Shidehara's view, lack of familiarity with European negotiation styles. He thus warned against participation at international conferences

29 On record in contemporary theory in Hintze O. [1907; 1917: 117-8]; Riezler K. [1907; 1913: 197-247; 1914: 23, 184-5]. 
which might even jeopardise the Japanese state or at least put its delegations at the mercy of other participants [Shidehara K. 1955: 136-7]. ${ }^{30}$

The adaptation of the dynamism introduced into Japanese political thought the revisionism necessary for the fabrication of a progressist colonial ideology as a response to European penetration into East and Southeast Asia as well as the South Pacific and precipitated the wars in East Asia and the Pacific 1931-1945. Often poorly equipped with information, usually lacking knowledge of East Asian languages and largely unaware of the revisionist push behind Japan's strategy, most European strategists, political decision-makers amd intellectuals around 1900 expected that Russia was the overall target of the expansion of Japanese rule and, in taking this view, unwillingly paved the way themselves for the eventual removal, after much further bloodshed, of European control of East and Southeast Asia and the largest part of the South Pacific.

\section{REFERENCES}

\section{Sources:}

Aizawa Seishisai, Shinron 新論 [in:] Imai Usaburō 今井宇三郎 (ed.) (1973), Nihon shisō taikei 日本思想大系, vol. 53: Mitogaku 水戸学, Iwanami shoten 岩波書店, Tokyo, 49-158.

Beer Max (1915), Das Regenbogenbuch, Wyss, Bern.

Brixianus Organtinus (1605), Historica Relatio de omnibus Iaponiae regnis [in:] Hay John (ed.), De rebus Iaponicis, Indicis et Pervanis epistolae recentiores, Nutius, Antwerp, 203-232.

Bukhari al-Jauhari (1603), Taj us-Salatin (The Crown of All Kings), Hussain Khalid M. (ed.) (1992), Dewan Bahasa dán Pustaka, Kuala Lumpur.

Cleyer Andreas (1685), [Tagebuch], [in:] Kraft Eva Susanne (ed.) (1985), Tagebuch des Kontors zu Nagasaki auf der Insel Deshima, Bonner Zeitschrift für Japanologie, Bonn.

Dutch East India Company, Heeren Zeventien to the Governor General and the counsels at Batavia, 6 December 1637 [in:] Nachod Oskar (ed.) (1897), Die Beziehungen der Niederländischen Ostindischen Kompagnie zu Japan im siebzehnten Jahrhundert, Pass \& Garleb, Berlin, CLVI-CLX.

Falkenegg Ledersteger Alois Paul Baron von (1905), Japan, die neue Weltmacht. Politische Betrachtungen, Boll \& Pickardt, Berlin.

Fukuzawa Yukichi 福澤諭吉 (1875), Bunmeiron no gairyaku 文明論之概略, Matsuzawa Hiroaki 松沢弘陽 (ed.) (1997), Iwanami shoten 岩波書店, Tokyo.

German Empire, Großer Generalstab, Kriegsgeschichtliche Abteilung (1908), Erfahrungen außereuropäischer Kriege neuester Zeit, part II: Aus dem russisch-japanischen Kriege. 1904 bis 1905, issue 43/44, Mittler, Berlin.

Gotenjiku-zu 五天笈図 (map of the world), fourteenth century, ed. [in:] Whitfield Peter (1994), The Image of the World, British Museum Press, London, 23; Nanba Matsutarō 南波松太郎 (ed.) (1973), Old Maps in Japan, Sōgensha 創元社, Osaka, 160-177.

${ }^{30}$ For a complaint of the lack of fluency in English see Makino N. [1978: 34-5, 187]. For a study see Shimazu N. [2017: 101-23, esp. 107]. 
Greiner Helmuth (no date), Welche Nachrichten besaß der deutsche Generalstab über Mobilmachung und Aufmarsch des französischen Heeres in den Jahren 1885-1914? Wie wurden sie ausgewertet und wie lagen die tatsächlichen Verhältnisse? Ms. Freiburg: BundesarchivMilitärarchiv, RH 61/398 = W 10/50267, fol. 001-157.

Hayashi Shihei 林子平(1738-1793) (1785/1916), Kaikoku heidan 海国兵談, new edn, Tonansha 図南社, Tokyo, separate pagination [also in: Yamagishi Tokuhei 山岸徳平 and Sano Masami 佐野正巳 (ed.) (1978), Shinpen Hayashi Shihei zenshū 新編林子平全集, vol. 1: Heigaku 兵学 Dai-ichi Shobō 第-書房, Tokyo, 77-288; facsimile of the edn by Asaka Gorō 安積五郎 (1856), [in:] ibid., 313-984].

Higashikuze Michitomi 東久世通禧 (1992), Nikki 日記, vol. 1, Kasumi Kaikan 霞会館, Tokyo. Hintze Otto (1907/1941), Imperialismus und Weltpolitik [in:] Hintze O, Staat und Verfassung, ed. Hartung Fritz (1941), Koehler \& Amelung, Leipzig, 447-459, at 459 [first published in: Internationale Wochenschrift für Wissenschaft, Kunst und Technik 1 (1907), 593-605, 631-636]; [reprinted in: Hintze, Staat und Verfassung, ed. Fritz Hartung (1941), Koehler \& Amelung, Leipzig, pp. 447-459].

Hintze Otto (1917), Imperialismus und Weltpolitik [in:] Die deutsche Freiheit, 114-169. Honda Toshiaki 本多利明 (1970), Kaibo Seiryō 海保青陵, Iwanami shoten 岩波書店, Tokyo. Japan, Gaimushō 外務省, Gaikoku jimu sōtoku 外国事務総督 (1938), “Gaikō ni kan suru fukokusho 外交に関スル布告書” [note by the Meiji government, dated 8 February 1868, $=15$ th day of the first month of year Keio 4 , on the relations between Japan and its treaty partners relating to the recognition of the existing treaties, by Ökubo Toshimichi 大久保利道 and Mutsu Munemitsu 陸奥宗光], [ in:] Dai Nihon gaikō monjo 大日本外交文書, 97 (1), Nihon Kokusai Kyōkai, Tokyo, 227-228

Japanese declaration of war on the German Empire, dated 23 August 1914; German version printed in Norddeutsche Allgemeine Zeitung [30 August 1914: 2]; Frankfurter Zeitung [29 August 1914: Erstes Morgenblatt, 2]. Japanese version in: Nihon Gaikô Monjo 日本外交文書, Taisho San-nen 大正三年 (1966), vol. 3, nr 240, Nihon Kokusai Kyōkai, Tokyo, 217.

Japan, Monbushō文部省 (1916), Nan'yō shinsen ryōchi shisatsu hōkoku 南洋新占領地視察領地視察 報告, Monbushō 文部省, Tokyo.

Japan, Monbushō 文部省 (1927), Nan'yō guntō chōsa shiryō 南洋群島調査資料, Monbushō 文部省, Tokyo.

Japan, Nan'yō chō 南洋庁 (1927), Annual Report ... for the Year 1926 (1927), Nan'yō chō 南洋庁, Tokyo.

Japan, Nan'yō chō 南洋庁 (1930), Annual Report ... for the Year 1929, Nan'yō chō 南洋庁， Tokyo.

Japan, Takumushō 拓務省, Takumukyoku 拓務局 (ed.) (1937-1938), Manshū nōgyō imin no genkyō 満州農業移民の現況, Takumukyoku 拓務局, Tokyo.

Japan，Takumushō拓務省 (ed.) (1938), Manshū nōgyō imin ni tsuite 満州農業移民に就いて， Takumukyoku 拓務局, Tokyo.

Kaempfer Engelbert (2001), Heutiges Japan, ed. Michel Wolfgang and Terwiel Barend Jan, vol. 1 (Kaempfer, Werke, vol. 1, part 1), iudicium, Munich.

Kaneko Kentarō 金子堅太郎 (1904a), Organisation eines konstitutionellen Staates [in:] Stead Alfred (ed.), Unser Vaterland Japan, Seemann, Leipzig, 28-41.

Kaneko Kentarō (1904b), The Yellow Peril is the Golden Opportunity for Japan [in:] North American Review, 179, 576 (November), 641-648.

Katō Hiroyuki 加藤弘之 (1870), Shinsei tai'i 真政大意 (ed.) [in:] Jiyū minken hen 自由民権編 (1992), vol. 1, Nihon hyōronsha 日本評論社, Tokyo, 85-108. 
Katō Hiroyuki 加藤弘之 (1893), Der Kampf ums Recht des Stärkeren und seine Entwicklung, the author, Tokyo [further edn (Friedländer, Berlin, 1894)].

Kōtoku Shūsui 幸徳秋水 (1901), Teikokushugi 帝国主義 (ed.) Yamaizumi Susumu 山泉進 (2004), Iwanami Shoten 岩波書店, Tokyo.

Lauenstein Otto von (1905), Report on the Russo-Japanese War, 10 December 1905, copies, Ms. Munich: Bayerisches Hauptstaatsarchiv, Abt. IV: Kriegsarchiv, Generalstab 234: 1-33 [also, Ms. Freiburg: Bundesarchiv-Militärarchiv PH 3/653].

League of Nations, Mandate on the maintenance of colonial rule, dated 17 December 1920, [in:] Pauwels Peter Carel (1936), The Japanese Mandate Islands, Batavia, LL.D. thesis, s.n, 147-149.

Makino Nobuaki 牧野伸顕 (1978), Kaikoroku 回顧録, vol. 2, Chūōkōronsha 中央公論社， Tokyo.

Marmande R. de (1904), French Public Opinion and the Russo-Japanese War, Fortnightly Review, 82, 317-327.

Ninagawa Arata 蜷川新 (1919), Les réclamations japonaises et le droit international, Pedone, Paris.

Nitobe Inazō 新渡戸稲造 (1920), Japanese Colonization [in:] Asiatic Review. Fourth Series, vol. 16, 113-121 [first published in: Proceedings. The Japan Society of London (1919); also [in:] Nitobe (1972), The Works, vol. 23, University of Tokyo Press 東京大学出版会, Tokyo, 111-120].

Okakura Tenshin 岡倉天心 (1903), The Ideals of the East, Murray, London.

Okakura Tenshin 岡倉天心 (1943), Japan's Innate Virility. Selections from Okakura and Nitobe, Hokuseidō shoten 北星堂書店, Tokyo.

Ōkawa Shūmei 大川周明 (1922), Kakumei Yōroppa to Fukkō Ajia 革命欧羅巴と復興亜細亜, Yūzonsha 猶存社, Tokyo.

Ōkawa Shūmei 大川周明 (1926), Nihon oyobi Nihinjin no michi 日本及日本人の道, Kōchisha shuppanbu 行地社出版部, Tokyo.

Ostwald Paul (1922), Japans Entwicklung zur modernen Weltmacht, Schroeder, Bonn.

Pauwels Peter Carel (1936), The Japanese Mandate Islands, Batavia, LL.D., thesis, s.n..

Peace treaty of Shimonoseki between China and Japan, 17 April 1895, Art. I, [in:] Parry Clive (ed.) (1981), The Consolidated Treaty Series, vol. 181, Oceana, Dobbs Ferry, p. 217.

Riezler Kurt (1907), Die Weltpolitik im Jahre 1906, [in:] Halle Ernst von (ed.), Die Weltwirtschaft. Ein Jahr- und Lesebuch, vol. 2, Teubner, Leipzig and Berlin, 1-13.

Riezler Kurt (1913), Die Erforderlichkeit des Unmöglichen. Prolegomena zu einer Theorie der Politik und zu anderen Theorien, G. Müller, Munich.

Riezler Kurt (1914) [under the pseudonym J. J. Ruedorffer], Grundzüge der Weltpolitik in der Gegenwart, Deutsche Verlags-Anstalt, Stuttgart.

Rōyama Masamichi 蠟山政道 (1941), Foreign Policy of Japan. 1914-1939, Japanese Council, Institue of Pacific Relations, Tokyo.

Sakuma Seiichi, The Duty of Japan towards Asia in Her Self-Interest [1916], [in:] O'Connor Peter (ed.) (2005), Japanese Propaganda. Selected Readings. Series 2: Pamphlets. 18911939, vol. 1, Global Oriental, Tokyo and Folkestone, 9-15.

Schlieffen Alfred Graf von (1905), Operational Study East, January-March 1905, Ms. Munich: Bayerisches Hauptstaatsarchiv, Abt. Kriegsarchiv, Konrad Krafft von Dellmensingen Papers, 336, first inside front cover, verso to second inside front cover recto.

Schnee Heinrich (1922), Die deutschen Kolonien unter fremder Mandatsherrschaft, Quelle \& Meyer, Leipzig.

Schnee Heinrich (1941), Die deutschen Kolonien vor, in und nach dem Weltkrieg, Quelle \& Meyer, Leipzig. 
Scott C. (1901), Telegraphic Message by Sir C. Scott, British representative at St Petersburg, to the Marquess of Lansdowne, 26 March 1901, [in:] United Kingdom of Great Britain and Ireland (1904), Correspondence Respecting the Russian Occupation of Manchuria and Newchwang, nr 34 (Cd 1936 = China 2), HMSO, London, 16.

Seibold Louis (1921), Japan. Her Plans and Purposes [alternative title: Japan. Her Vast Military Undertakings and World Expansion]. A Series of Articles, New York Herald, New York.

Shidehara Kijūrō (1955), Shidehara Kijūrōo 幣原喜重郎, Shidehara heiwa zaidan 幣原平和財団, Tokyo.

Shiga Shigetaka 志賀重昂 (1889), Nan'yō jiji 南洋時事, Maruzen丸善, Tokyo [ed. in: Shiga Shigetaka zenshu 志賀重昂全集 (1929), vol. 3，Nihon Tosho Sentā 日本図書センター， Tokyo].

Shimada Saburō 嶋田三郎 (1919), Welcome to the League of Nations, s.n., Tokyo.

Shizuki Tadao 志筑忠雄 (1801/1914), Sakoku-ron 鎖国論, ed. [in:] Bunmei genryū sōsho 文明源 流叢書, vol. 2, Kokusho Kankōkai 国書刊行会, Tokyo, 182-217.

Siebold Alexander von (1900), Der Eintritt Japans in das europäische Völkerrecht, Tamai 玉井, Berlin.

Speelman Cornelis (1685), Memorandum for the dienaars on Dejima, implementing rules by the Heeren Zeventien, 1635-1652 [in:] Cleyer Andreas (1685), [Tagebuch], [in:] Kraft Eva Susanne (ed.) (1985), Tagebuch des Kontors zu Nagasaki auf der Insel Deshima, Bonner Zeitschrift für Japanologie, Bonn, pp. 189-190, s. d. 29 June 1685, [The Hague: Algemeen Rijksarchief, VOC 700, fol. 295-296].

Stead Alfred (1904), Why Japan will Win, Fortnightly Review, 82, 996-1006.

[Takayama 高山], Chogyū zenshū 橒牛全集 (1930), vol. 5, Hakubunkan 博文館, Tokyo.

Tokutomi Sohō 徳富蘇峰1863-1957 (1894), Dai Nihon bōchō ron 大日本膨張論, Minyūsha 民友 社, Tokyo.

Ukita Kazutami 浮田和民 (1901), Teikoku shugi to kyōiku 帝国主義と教育, Minyūsha 民友社， Tokyo, 166-170.

Ukita Kazutami 浮田和民 (1902), Teikoku shugi no risō 帝国主義の理想, nr 8, [in:] Kokumin Shinbun 国民新聞, 21 January.

Ukita Kazutami 浮田和民 (1909), Taiyō no dokusha ni tsugu 太陽の読者に告ぐ, [in:] Taiyō 太陽/ The Sun, 15(2), February, 1-2.

United Kingdom of Great Britain and Ireland, Committee of Imperial Defense, Historical Section (1912), Official History (Naval and Military) of the Russo-Japanese War, vol. 2: Liao-Yang, The Sha Ho, Port Arthur, HMSO, London.

Varenius Bernhardus (1673), Descriptio Regni Japoniae et Siam, Hayes, Cambridge.

Vollerthun Waldemar (1920), Der Kampf um Tsingtau. Eine Episode aus dem Weltkrieg 1914/1918 nach Tagebuchblättern, Hirzel, Leipzig.

Yanaihara Tadao 矢内原忠雄 (1935), Nan'yō shotō no kenkyū 南洋諸島の研究, [in:] Yanaihara (1963), Yanaihara Tadao zenshū 矢内原忠雄全集, vol. 2, Iwanami shoten 岩波書店, Tokyo, $1-458$.

Yanaihara Tadao 矢内原忠雄 (1939), Pacific Islands under Japanese Mandate, Kelly \& Walsh, Shanghai.

\section{Secondary literature:}

Amino Yoshihiko 網野善彦 (1995), Les Japonais et la mer, Annales ESC 50, 235-238.

Amino Yoshihiko 網野善彦 (2003), Umi to rettō no chūsei 海と列島の中世, Kōdansha 講談社, Tokyo.

Araki Tadao Johannes (1959), Geschichte der Entstehung und Revision der ungleichen Vertrage mit Japan (1853-1894), University of Marburg, Ph.D. thesis, typescript. 
Auslin Michael R. (2004), Negotiating with Imperialism. The Unequal Treaties and the Culture of Japanese Diplomacy, Harvard University Press, Cambridge, MA.

Aydin Cemil (2007), The Politics of Anti-Westernism in Asia. Visions of World Order in PanIslamic and Pan-Asian Thought, Columbia University Press, New York.

Beasley William Gerald (1987), Japanese Imperialism. 1894-1945, Oxford University Press, Oxford.

Burkman Thomas W. (2008), Japan and the League of Nations, University of Hawaii Press, Honolulu.

Clulow Adam (2013), The Company and the Shogun. The Dutch Encounter with Tokugawa Japan, Columbia University Press, New York.

Clyde Paul Hibbert (1935), Japan's Pacific Mandate, Macmillan, New York.

Duus Peter (1992/1996), Shokuminchi naki teikokushugi 植民地なき帝国主義, [in:] Shisō 思想 814, April, 105-121 [English version s. t.: Imperialism without Colonies. The Vision of aGreater East Asia Co-Prosperity Sphere, in Diplomacy and Statecraft 7, 54-72].

Fairbank John King and Teng Ssu Yü [Dèng Sìyŭ] 邓嗣禹(鄧嗣禹) (1941), On the Ch'ing Tributary System, Harvard Journal of Asiatic Studies, 6(2): 107-218.

Gavin Masako (2004a), Shiga Shigetaka (1863-1927) and New Zealand as a Model for Japan, [in:] Starrs Roy (ed.), Japanese Cultural Nationalism. At Home and in the Asia Pacific, Global Oriental, Folkestone, 193-212.

Gavin Masako (2004b), Shiga Shigetaka. The Forgotten Enlightener, Routledge Curzon, London.

Gipouloux François (2011), The Asian Mediterranean. Port Cities and Trading Networks in China, Japan and Southeast Asia. $13^{\text {th }}-21^{\text {st }}$ Century, Elgar, Cheltenham and Northampton, MA, 84-92.

Gotō Ken'ichi 後藤乾- (1992), Taiwan to Nan'yō - “nanshin” kanshin mondai tono kanren de -台湾と南洋-「南進」問題との関連で-, [in:] Ōe Shinobu 大江志乃夫 (ed.), Kindai Nihon to shokuminchi 近代日本と植民地, vol. 2, Iwanami Shoten 岩波書店, Tokyo, 147-175.

Hamashita Takeshi 濱下武志 (1997), Chōkō shisutemu to kindai Ajia 朝貢システムと近代アジア， Iwanami shoten 岩波書店, Tokyo.

Hashikawa Bunzō 橋川文三 (1964), Chō kokkashugi 超国家主義, Chikuma shobō 筑摩書房, Tokyo.

Hatano Sumio 波多野澄雄 (1986), Nihon kaigun to “nanshin" 日本海軍と「南進, [in:] Shimizu Hajime 清水元(ed.), Ryōtaisenkanki Nihon-Tōnan Ajia kankei 両大戦間期日本東南アジア関 係の諸相, Ajia Keizai Kenkyūjo アジア経済研究所, Tokyo, 207-236.

Hevia James Louis (2009), Tribute, Asymmetry and Imperial Formations. Rethinking Relations of Power in East Asia, Journal of American-East Asian Relations, 16, 69-83 [reprinted in a revised version in: Wills Jr John Elliot (ed.) (2011), Past and Present in China's Foreign Policy. From 'Tribute System' to 'Peaceful Rise', Merwin/Asia, Portland, ME, 61-76]

Hiraishi Naoaki 平石直明 (1998), Kindai Nihon no kokusai chitsujokan to Ajia shugi 近代日 本の国際秩序観とアジア主義, [in:] 20 seiki shisutemu20 世紀システム, vol. 1, Tōkyō Daigaku Shuppankai 東京大学出版会, Tokyo, 176-211.

Hirano Yoshitarō 平野義太郎, Kiyono Kenji 清野謙次 (1942), Taiheiyō no minzoku seijigaku 太平洋の民族政治学, Nihon hyōron sha 日本評論社, Tokyo.

Hora Tomio 洞富雄 (1977), Bakumatsu ishinki no gaiatsu to teikō 幕末維新期の外圧と抵抗， Azekura shobō 校倉書房, Tokyo.

Hotta Eri 掘田江理 (2007), Pan-Asianism and Japan's War. 1931-1945, PalgraveMacmillan, Basingstoke and New York. 
Irie [Iriye] Akira 入江昭 (1966), Nihon no gaikō 日本の外交, Chūōkōronsha 中央公論社， Tokyo.

Irie [Iriye] Akira入江昭 (1997), Cultural Internationalism and World Order, Johns Hopkins University Press, Baltimore and London.

Ishii Kanji 石井寛治 and Sekiguchi Hisashi 関口尚志 (ed.) (1982), Sekai shijō to bakumatsu kaikō 世界市場と幕末開港, Tōkyō Daigaku Shuppankai 東京大学出版会, Tokyo.

Jacob Frank (2014), Anti-Russian Secret Actions. The Kokuryusha and the Russo-Japanese War, Altre modernità, 11, 111-119.

Joos Joēl (2011), The Genyōsha (1881) and Premodern Roots of Japanese Expansionism, [in:] Saaler Sven and Szpilman Christoper W. A. (ed.), Pan-Asianism. A Documentary History, vol. 1, Rowman \& Littlefield, Lanham, MD, 61-68.

Kibata Yōichi 木畑洋- (2002), 1900 nen zengo no teikokushugi sekai taisei to Nihon -九○○年前 後の帝国主義世界体制と日本, [in:] Teikokushugi no jidai to genzai. Higashi Ajia no taiwa 帝国 主義の時代と現在: 東アジアの対話, Shūeisha 集英社, Tokyo, 20-30.

Kublin Hyman (1959), The Evolution of Japanese Colonialism, Comparative Studies in Society and History, 2, 67-84.

Lynn Hyung-Gu (1998), A Comparative Study of the Tōyō Kyōkai and the Nan'yō Kyōkai, [in:] Fuess Harald (ed.), The Japanese Empire in East Asia and Its Postwar Legacy, iudicium, Munich, 65-95.

Maanen-Helmer Elizabeth van (1929), The Mandates System in Relation to Africa and the Pacific Islands, King, London.

Macmillan Margaret (2001), Peacemakers. The Paris Peace Conference of 1919 and Its Attempt to End War, Murray, London.

Maeda Ai 前田愛 (1973), Meiji kokken shisō to nashonarizumu. Shiga Shigetaka to Nichiro sensō 明治国権思想とナショナリズム一志賀重昂と日露戦争, [in:] Dentō to gendai 伝統と現代 20, 46-53.

Mancall Mark (1970), The Ch'ing Tribute Sysem [in:] Fairbank John King (ed.), The Chinese World Order, second ed., Harvard University Press, Cambridge, MA, 63-89.

Maruyama Masao 丸山眞男 (1952), Nihon seiji shisōshi kenkyū 日本政治思想史研究, Tōkyō Daigaku Shuppankai 東京大学出版会, Tokyo.

Maruyama Masao 丸山眞男 (1974), Studies in the Intellectual History of Tokugawa Japan, University of Tokyo Press 東京大学出版会, Tokyo.

Matsukata Fuyuko 松方冬子 (2018), Contacting Japan. East India Company Letters to the Shogun [in:] Clulow Adam and Mostert Tristan (ed.), The Dutch and English East India Companies. Diplomacy, Trade and Violence in Early Modern Asia, Amsterdam University Press, Amsterdam, 79-99.

Mitani Hiroshi 三谷博 (2006), Escape from Impasse. The Decision to Open Japan, University of Tokyo Press 東京大学出版会, Tokyo.

Miwa Kimitada 三輪公忠 (1967), Crossroads of Patriotism in Imperial Japan. Shiga Shigetaka (1863-1927), Uchimura Kanzō (1861-1930) and Nitobe Inazō (1862-1933), Princeton University, Ph.D. thesis, typescript.

Miwa Kimitada 三輪公忠 (1970), Shiga Shigetaka (1863-1927). A Meiji Japanist's View of and Actions in International Relations, Sophia University, Tokyo.

Miwa Kimitada 三輪公忠 (2007), Pan-Asianism in Modern Japan. Nationalism, Regionalism and Universalism [in:] Saaler Sven and Koschmann Julian Victor (eds.), Pan-Asianism in Modern Japanese History, RoutledgeCurzon, London and New York, 21-33.

Nakano Ryōko 中野涼子 (2013), Asianism versus Internationalism?, [in:] Nakano, Beyond the Western Liberal Order. Yanaihara Tadao and Empire as Society, PalgraveMacmillan, Basingstoke and New York, 115-141. 
Nish Ian Hill (1966), The Anglo-Japanese Alliance, Athlone, London.

Norman Egerton Herbert (1944), The Genyosha. A Study in the Origins of Japanese Imperialism, Pacific Affairs, 17, 261-284.

Ōmori Mikihiko 大森美紀彦 (1999), Kakumei shisōka kara tōseishisōka e. Ōkawa Shūmei ni okeru kakumei shisō no tenkan 革命思想家から統制思想家へ一大川周明における革命思想の 転換, [in:] Hikaku Nihon kenkyūkai 比較日本研究会 (ed.), Seijibunka政治文化, 14, 47-68.

Ōshima Akihide 大島明秀 (2005), 19 seiki Kokugakusha ni okeru Shizuki Tadao yaku “Sakoku ron" no juyō to Hirata Kokugaku 十九世紀国学者における志筑忠雄訳『鎖国論』 の受容と平田国学, [in:] Nihon bungei kenkyū 日本文藝研究57, 39-63.

Ōshima Akihide 大島明秀 (2006), Kinsei kōki Nihon ni okeru Shizuki Tadao yaku “Sakoku ron” no juyō 近世後期日本における志筑忠雄訳『鎖国論』の受容, [in:] Yōgaku 洋学, 14, $1-32$.

Ōshima Akihide 大島明秀 (2009), “Sakoku” to iu gensetsu「鎖国」という言説, Minerva Shobō ミネルヴァ書房, Kyōto.

Peattie Mark R. (1984), Japanese Attitudes toward Colonialism, [in:] Myers Ramon Hawley and Peattie (ed.), The Japanese Colonial Empire, Princeton University Press, Princeton, pp. 80-127.

Peattie Mark R. (1988a), Nan'yō. The Rise and Fall of the Japanese in Micronesia. 1885-1945, University of Hawaii Press, Honolulu.

Peattie Mark R. (1988b), The Japanese Colonial Empire. 1895-1945, [in:] Duus Peter (ed.), The Cambridge History of Japan, vol. 6, Cambridge University Press, Cambridge, 217-270.

Peattie Mark R. (1996), Nanshin. The "Southward Advance" 1931-1941 as a Prelude to the Japanese Occupation of Southeast Asia, [in:] Duus Peter (ed.), The Japanese Wartime Empire, Princeton University Press, Princeton, 189-242.

Perdue Peter C. (2015), Empires and Frontiers in Continental Eurasia [in:] Reinhard Wolfgang (ed.), Empires and Encounters. 1350-1750, Belknap Press, Cambridge, MA and London, $55-218$, at 58-107.

Purcell Jr. David Campbell (1967), Japanese Expansion in the South Pacific. Philadelphia: University of Pennsylvania, Ph. D. thesis, typescript.

Saaler Sven (2011), The Emergence of Pan-Asianism as an Ideal of Asian Identity and Solidarity [in:] Saaler Sven and Szpilman Christopher W.A. (eds.), Pan-Asianism. A Documentary History, vol. 2, Rowman \& Littlefield, Lanham, MD, 1-41.

Saxon Timothy D. (2000), Anglo-Japanese Naval Cooperation. 1914-1918, Naval War College Review, 53, 62-92, https.//digitalcommons.liberty.edu/cgi/viewcontent.cgi? referer $=\&$ article $=1004 \&$ context $=$ hist_fac_pubs], accessed 30.07.2019.

Seaton Philip A. (2017), Japanese Empire in Hokkaidō, [in:] Oxford Research Encyclopedia of Asian History, esp. at 11 f., http./ / oxfordre.com/ asianhistory/, accessed 30.07.2019.

Seligmann Matthew S. (2007), Germany, the Russo-Japanese War and the Road to the Great War, [in:] Kowner Rotem (ed.), The Impact of the Russo-Japanese War, Routledge, London, 109-123.

Shimazu Naoko 島津直子 (1998), Japan, Race and Equality. The Racial Equality Proposal of 1919, Routledge, London and New York.

Shimazu Naoko 島津直子 (2006), Jinshu sabetsu teppai an. Pari kōwa gaikō no hitomaku 人種差別 撤廃案 - パリ講和外交の-幕, [in:] Kensei no seijigaku. Banno Junji kinen ronbunshū 憲政の政 治学坂野潤治記念論文集, Tōkyō Daigaku Shuppankai 東京大学出版会, Tokyo, 149-170.

Shimazu Naoko 島津直子 (2017), A Cultural History of Diplomacy. Reassessing the Japanese "Performance" at the Paris Peace Conference of 1919, [in:] Zachmann Urs Matthias (ed.), Asia after Versailles. Asian Perspectives on the Paris Peace Conference and the Interwar Order. 1919-1933, Edinburgh University Press, Edinburgh, 101-123. 
Shimizu Hajime 清水元 (1991), Meiji chūki no "nanshinron" to “kantaiheiyō" yokosō no genkei. Shiga Shigetaka "Nanyō jiji” wo megutte 明治中期の「南進論」と「環太平洋」構 想の原型 - 志賀重昂「南洋時事」をめぐって, Ajia keizai アジア経済, 32 (9), 2-20.

Suzuki Shōgo 鈴木昭吾 (2009), Civilization and Empire. China and Japan's Encounter with European International Society, Routledge, Abingdon, Oxon.

Szpilman Christopher W. (2015), Kindai Nihon no kakushin ron to Ajia shugi 近代日本の革新論 とアジア主義, Ashi shobō 芦書房, Tokyo.

Takeuchi Yoshimi 竹内好 (1963), Ajia-shugi no tenbō アジア主義の展望 [in:] Takeuchi Yoshimi, Ajia shugi, Chikuma shobō 筑摩書房, Tokyo, 7-66.

Takii Kazuhiro 瀧井-博 (2007), The Meiji Constitution. The Japanese Experience of the West and the Shaping of the Modern State, I-House Press アイハウスプレス, Tokyo.

Tashiro Kazui 田代和生 (1982), Foreign Relations during the Edo Period. Sakoku Reexamined, Journal of Japanese Studies, 8, 283-306.

Toby Ronald P. (1984), State and Diplomacy in Early Modern Japan. Asia in the Development of the Tokugawa Bakufu, Princeton University Press, Princeton.

Tsuzuki Chūshichi 都築忠七 (2000), Japan in 1825. A Crisis in Seclusion [in:] Tsuzuki Chūshichi, The Pursuit of Power in Modern Japan. 1825-1995, Oxford University Press, Oxford, 19-37.

Treat Payson Jackson (1932), Diplomatic Relations between the United States and Japan, vol. 1, Stanford University Press, Stanford and London.

Wakabayashi Bob Tadashi (1986), Anti-Foreignism and Western Learning in Early-Modern Japan. The New Theses of 1825, Harvard University Press, Cambridge, MA.

Wáng Gung[Gēng]-Wŭ 王庚武 (王賸武) (2013), Renewal. The Chinese State and the New Global History, Chinese University Press, Hong Kong.

Wallentowitz Anneli (2011), "Imperialismus" in der japanischen Sprache am Übergang vom 19. zum 20. Jahrhundert, Vandenhoeck \& Ruprecht, Göttingen.

Weststeijn Arthur (2017), Provincializing Grotius. International Law and Empire in a SeventeenthCentury Malay Mirror [in:] Koskenniemi Martti Antero, Rech Walter and Jiménez Fonseca Manuel (ed.), International Law and Empire. Historical Explorations, Oxford University Press, Oxford, 21-38.

Zachmann Urs Matthias (2016), Souveränität, Gleichheit und regionale Autonomie. Die Entwicklung des außenpolitischen Denkens Japans im 17.-19. Jahrhundert [in:] Vollmer Klaus (ed.), Japan im vormodernen Ostasien, Röhrig, St Ingbert, 162-184.

Zhāng Yŏngjìn 张勇进 (張勇進) and Buzan Barry Gordon (2012), The Tributary System as International Society in Theory and Practice, Chinese Journal of International Politics, 5 , 3-36.

Zhào Tīng Yáng 趙汀陽 (2020), Alles unter dem Himmel, Suhrkamp Berlin [first published, China CITIC Press, Beijing 2016].

Zöllner Reinhard (2003), Verschlossen wider Wissen. Was Japan von Kaempfer über sich lernte, [in:] Klocke-Daffa Sabine, Scheffler Jürgen and Wilbertz Gisela (eds.), Engelbert Kaempfer (1651-1716) und die kulturelle Begegnung zwischen Europa und Asien, Lippisches Landesinstitut, Lemgo, 185-209.

Harald Kleinschmidt, received his doctoral degree from the University of Göttingen in 1978 and his habilitation from the University of Stuttgart in 1985; he taught at Stuttgart from 1980 to 1989, was professor of the history of international relations at the University of Tsukuba (Japan) from 1989 to 2015 and has been visiting professor of the history of international relations at the University of Hildesheim (Germany) since 2016. 